\title{
A Comparative Study of Punishment in Buddhist and Western Educational Psychology
}

\author{
Wickrama Kankanamge Don Keerthirathne ${ }^{1 *}$
}

\section{ABSTRACT}

This paper aims to offer a comparative examination of punishment methods in Buddhist and western education psychology. The Buddhist concept of punishment is more humanistic than punishment in criminology and in western educational psychology. Although the concept 'punishment' in western education psychology is somewhat similar to its Buddhist counterpart, I argue there are some lessons that can be taken from Buddhist psychology to direct punishment theories in western psychology towards a more humanistic approach. Most of mental punishments used in western psychology can identify in Buddhist psychology too. Therefore, it can be argued that some punitive methods in western psychology were not newly introduced by western psychologists. When conducting this research, it is expected to do it from critical and analytical perspectives in combination with descriptive and explanatory methods from the study of teachings in Sutta Pitaka and Vinaya pitaka. Furthermore, research works of previous scholars are examined as secondary sources to direct the research paper towards a more critical approach. This research would contribute to the enhancement of the knowledge of teachers, principals, curriculum developers, theory makers and psychologists, at both practical and theoretical level, to use punishment in a proper way and improve the quality of education while children receive and prevent them from dropping out of school.

Keywords: Buddhism, Buddhist Psychology, Education Psychology, Punishment

The concept of "punishment” is a controversial issue in both western and eastern school systems due to the strengthening of human rights at a deeper level compared to the past. However, it is not a concept totally omitted from the school system since it is used by teachers and school authorities as a mean of disciplining of students. “The Buddhist concept of punishment”, which is based on a humanistic approach, has been influential in many ways when re-arranging the punishment process in the present educational system towards a more humanistic approach due

\footnotetext{
${ }^{1}$ School of Philosophy and Social Development, Shandong University, Jinan, PR China, Pasdunrata National College of Education, Sri Lanka

*Responding Author

(C) 2016 I W Keerthirathne; licensee IJIP. This is an Open Access Research distributed under the terms of the Creative Commons Attribution License (http://creativecommons.org/licenses/by/2.0), which permits unrestricted use, distribution, and reproduction in any Medium, provided the original work is properly cited.
} 


\section{A Comparative Study of Punishment in Buddhist and Western Educational Psychology}

to integration with each other over several decades. However, there are commonalities and differences in the concept of punishment in Buddhist and western education psychology. As I believe, there are still many lessons that can be taken from Buddhist psychology to direct the punishment process in the present educational system towards a more humanistic approach than what is the case at present. Moreover, this kind of research would help teachers, principles, curriculum developers, theory makers and psychologists to use punishment methods at a practical as well as a theoretical level properly to implement quality education without damaging the personality of the child.

\section{The Concept Of Punishment In Buddhism}

The action taken against those who violate Vinaya rules can be considered as punishment according to the teachings in Vinaya Pitaka. The process of Punishment in Buddhism aims to moralize disciples in order to stop mal practices which obstruct their way to Nibbana, is more psychological than physical. The main function of punishment in Buddhism is to help disciples reach Nibbana, i.e. punishment is given in order to prevent them from engaging into practices that would raise obstacles in their efforts to achieve Nibbana. The history of the concept of punishment in Buddhism starts from the end of the first 20 years of the Buddha's enlightenment. During the first 20 years the Buddha did not want to impose law as well as to punish his disciples as they had been behaved well towards the prescribed way to Nibbana. Those disciples aimed only at the ultimate goal than any other worldly things which obstruct one's way to Nibbana. As a result of that, the Buddha had to preach only Ovada Patimokkhha in order to remind them of the characteristics of a monk who follows his teachings and shows the way they should practice in order to become an ideal Shramana. Once, the Buddha said that Bikkhus who lived during these first twenty years made him happy due to their strong discipline and it was enough for them to be reminded of the nature of a Shramana to cultivate their spiritual personality (MNI: 122 PTS).

Since the Buddha did not want to put pressure on his disciples with unwanted rules, he took necessary steps to impose law and punishment when the right time came. Hence, it is obvious that there is an important psychological background behind the punitive process in Buddhist psychology. Once, Rev Sarpuththa asked the Buddha to impose rules for the correct functioning of the Sangha, and the Buddha replied to him that he would not impose law until defilements emerged (Asawattaniya Dhamma) (MN:42 PTS). With respect to this case, I believe that the Buddha had thought the need of mental relaxation when attaining the ultimate goal and had shown the adverse affect of punishment which uproots human constructive ideas under such oppressive environment. However, with the passing of time due to the immoral practices of some monks, rules and punishments were introduced by the Buddha as Vinaya was the main factor that affected them in the long run of Sasana (vinayo nama sasanassa ayu) (SPa: 457).The Buddha's flexible policy regarding punishment astonished contemporary rulers as well as religious people. For example, once, King Kosala had the thought of "How the Buddha maintains strong

(C) The International Journal of Indian Psychology, ISSN 2348-5396 (e)| ISSN: 2349-3429 (p) | 33 


\section{A Comparative Study of Punishment in Buddhist and Western Educational Psychology}

discipline in his disciples without rod and weapons” (MN II: 118 PTS). It is important to point out that the Buddha treated punishment in the Sangha and punishment in the state context in slightly different ways. The beginning of judicial system and the concept of punishment in primitive societies can be seen in Agganna Sutta in Deegha Nikaya (DN III: 80 PTS).

\section{The Concept Of Punishment In Western Psychology}

In general use, punishment is defined as something meted out to a person who has committed a crime or engaged in some other anti-social and inappropriate behavior. Punishment in modern law aims to hurt the offender as well as to include retribution. In the modern law the offender is punished if s/he has done the wrong thing deliberately as a result of his own free will: in such case he is considered as guilty and is liable to punishment. Moreover, punishment is used as a means of social control to maintain the social equilibrium to a certain extent. Modern penology recognizes the need for changing the anti-social attitudes in to social ones. Punishment may involve prison time, a death sentence, fines, and the threat of going to hell, spanking or scolding according to its general sense as explained in present law (Miltenberger, 2008:122 ).

A similar interpretation can be seen even in modern psychology regarding punishment. According to psychologists, anything that decreases behavior is considered as punishment ${ }^{2}$. and aims at preventing the occurrence of the socially acceptable act in the future. As Anita argues, punishment involves the decreasing or suppression of one's behavior (Anita, 2006:239). According to Robber, punishment means "procedures in which aversive consequences are delivered to individuals when they engage in specific action” (Baron, 2008:447). In conventional learning situations, punishment is applied largely in classroom issues and in the process of management and psycho-motor skill development rather than in cognitive development ${ }^{3}$. In western psychology, slapping, spanking, pinching, shaking or hitting with belt or paddles are the main forms of physical punishment used by parents and teachers when disciplining children (Straus, 1991:503-561). It is even suggested by some that punishment methods like spanking and slapping are reasonable, while others consider them as abuse (Wade \& Tarvis, 2007:248). Yelling, scolding, fining and sulking are non corporal punishments used by both teachers and parents (Ibid). To psychologists, there are some psychologists who believe that even punishments of milder forms, like spraying water in the face or a firm "No" can have the same effect as more severe ones such as an electric shock (Ibid). Punishment used in Behavior Modification (BMod) theory is somewhat different from the general meaning of the concept “punishment”. In BMod theory, "punishment” refers to a process in which the consequences of behavior result to a future drop in the occurrence of that behavior (Miltenberger, 2008:122).

\footnotetext{
${ }^{2}$ www.livestrong.com/article/105661-behavior-modification Retrieved 26.10.2014

${ }^{3}$ www.learningandteaching.into/learning/behavior_mod.htm Retrieved 29th. 10.2014
}

(C) The International Journal of Indian Psychology, ISSN 2348-5396 (e)| ISSN: 2349-3429 (p) | 34 


\section{A Comparative Study of Punishment in Buddhist and Western Educational Psychology}

\section{Comparative Study Of Punishment In Buddhist And Western Education Psychology}

Buddhism which imposes only mental punishment upon the guilty party has implemented punitive methods: criticizing, depriving privileges, assigning demerits, ignoring, giving extra works, isolation of the offender, detention, probation, begging forgiveness even from laymen, stopping going out and banishment from one's society to another as solutions for occasions where disciplinary actions should be taken. Since Buddhism does not promote physical punishment, punitive methods in Buddhism are entirely psychological.

Sometimes in conventional learning situations the teacher assigns demerits, extra work, running laps and so on, which is called "presentational punishment” in behaviorism. Buddhism imposes these types of punishment especially in the case of novices for their wrong-doings. Sometimes, they are asked to fill the shrine yard with sand according to the offence they have committed. Assigning extra work is a common punishment even in prison, but it is more severe than the Buddhist concept of punishment and classroom punishments.

Criticizing, advising, and ordering are three common punitive methods that can be seen very often in general classroom situations (Santrock, 2006:175). When students display wrong behavior, the teacher criticizes the wrong doer personally as well as in front of the classroom, whereas, sometimes, the students are advised not to engage into such wrong doings again. There are some occasions where students obey the teachers only when the latter give them explicit orders, whereas they are reluctant or even avoid complying with the teachers' requests when they are criticized or advised and for such students, the teacher orders what she wants to do. However, the nature of the punishment, criticizing, advising, and ordering, depends on the teacher's personality. If the personality of the teacher consists of sound teacher competencies, the teacher would not impose hard and painful punishments on the students. These three methods can also be found among the Buddhist punitive methods, notably in the case of Chatuma. Once, two groups of Bhikkhus, who gathered in Chathuma, behaved in an indecent way by shouting and making loud noise. The Buddha, who observed it, summoned those Bhikkhus and asked them to leave the monastery, thus expelling them from the monastery. It is also mentioned in the relevant Sutta that the Buddha called them back to the monastery after allowing them to reach an understanding of the indecent behavior they had displayed (MN I:457 PTS). The lesson we learn from this incident is that the person who errs is not considered as a wrong-doer forever. This is the reason why the Buddha summoned these Bhikkhus back to the monastery. He/she can correct his/her error as well as she/he can appear in society like a moon which got rid of clouds after correcting his/her error (Dham: 172-173 PTS). The Angulimala Sutta provides a fine example to illustrate this concept. Though Angulimala earlier in his life was a murderer, having corrected his faults he later became an important character in the Buddhist world under the guidance of the Buddha. It is instructive to look at his example: he explains his life experience and the conciliation he got from the Buddha because of the Buddha's correct guidance (TGha: 97 PTS). Another important aspect of this incident is that King Kosala was to capture him dead or alive when he was a murderer, but the Buddha did not do any harm or did not use any weapon in order to rehabilitate 


\section{A Comparative Study of Punishment in Buddhist and Western Educational Psychology}

him. The character of Rev Angulimala testifies that offenders are motivated to do such crimes by their psycho-social and physical environment. This view is accepted even in modern psychology (Johnston \& Penny, undated: 131). Sometimes, in modern classrooms, when a student displays wrong behavior some teachers who have not improve their teaching qualities and competencies tend to label him/her as a wrong doer until he/ she leaves the school. The Buddhist teaching that "The person who errs is not a wrong-doer forever" is a fine example for such teachers to follow.

In the classroom teaching learning process and in the present judicial system, depriving privileges is used as a method to punish the offender. In behaviorism this is referred to as "removal punishment", which includes removing a stimulus. When a teacher or the parents take away privileges from a child or a teenager who has behaved inappropriately, this is called "removal punishment" (Anita, 2006:239) - in modern psychology, it is also known as "response cost" (Miltenberger, 2008:122). This is a serious mental punishment any offender can be given. However, some psychologists suggest using depriving privileges instead of hitting when a child displays wrong behavior (Carole, Carol, Deborah \& Lorin, 2007). Depriving privileges can be seen as a punitive method in Buddhist psychology as well. The Pattanikkujjana Sutta in Anguttara Nikaya gives an example of this type of punishment. Offering alms and providing for other needs of the Bhikkhus are privileges of laymen from the beginning of the Buddha Sasana. However, if laymen do not pay due respect to Bhikkhus, Dhamma and Sangha, in such occasions, the offerings of those (laymen) devotees are rejected by the Bhikkhus, which is called Pattanikkujjana Kamma. The main thing that happens under this punishment is that the Bhikkhus' bowl is turned upside down in front of those laymen who display misbehavior towards the Bhikkhus and the Buddha Sasana. The Pattanikkujjana Sutta offers explanations about the eight occasions this punishment can be given to a layman (AN IV: 61 PTS). Depriving

privileges is also a punishment given to a Bhikkhu who was subjected to Nissayakamma (Act of subordination). Such a Bhikku is compelled to live under a tutelage of another senior monk. In this case, rights and privileges are suspended until he completes Manatta and Parivasa according to the error he has committed.

Isolation is another method used in educational psychology in order to correct one's behavior (Santrock, 2006:176). In this case, the teacher asks fellow students to not socialize with the student who has displayed wrong behavior. According to the incident which took place in Ghositaramaya at Kosambanuwara (Kosambiya Sutta: 320 PTS) isolation is not a new method introduced by modern psychologists. Rev. Channa was also imposed "ignoring" with Brahmadanda. The person who is subjected to this punishment suffers mentally, at a higher degree than when he gets pain from physical punishment. Imposing Brahmadanda to Rev Channa was the occasion where the concept of punishment emerged in Buddhism.

Detention is another method used in present times to punish an offender. In modern classrooms, teachers assign detention for wasting time, repeated rule violation, not completing assignments and disrupting the class. In this punishment, students sometimes remain in the classroom, or in 


\section{A Comparative Study of Punishment in Buddhist and Western Educational Psychology}

detention rooms (if the school has one), where the student can be confined for a certain period of time. According to modern law, this is similar to the punishment given to those who are under probationary period. However, the process followed by modern law regarding probation is totally different in comparison to that of educational psychology and of Buddhist psychology. In Buddhism, this method can be seen functioning at a deeper level than in educational psychology. Completion of Manath and Parivasa is somewhat similar to this detention not regarding the depth of the process, but only in name. Length of detention in Buddhism is longer than modern classroom detention. While in detention, the monk who undergoes this process should complete a number of disciplinary actions in order to regain his purity. At schools, the length of the detention period should be short, e.g. in the order of 10-15 minutes since students are young and detention should happen only under the supervision of teachers (Santrock, 2006:176). At present, this type of punishment is rare due to the rise of the concept of "human rights". In Buddhism, the Bhikkhus who undergo Sangadisesa Apatti, which is considered as the second gravest offence, are liable to have this type of punishment.

Begging for forgiveness to restore trust and re-capture one's good standing in society is another punitive method used in Buddhism. In a similar way, in modern classroom education the teacher or the principal asks the wrong doer to beg forgiveness from teachers, parents and fellow students. Most of the times, this is done in front of all the students in the school or in front of the classmates in particular, during the daily morning assembly. A Bhikkhu who committed an offence should beg for the pardon even of a layman. This punishment is called Patisaraniya Kamma ("Act of reconciliation") according to the Sanghadisesa offence (Vin). Some psychologists introduce begging forgiveness as "reconciliation" rather than as a type of punishment pointing out that reconciliation differs from punishment. They argue that reconciliation is a process of restoring trust and bond between the guilty party and society. Intention of reconciliation is not to harm the offender. Furthermore, they reckon that for this reason reconciliation is sometimes referred to as "restorative" justice" (Fink, 2012:371). However, according to Buddhism, begging for forgiveness is an important mental punishment as well as restoration.

Excommunicating from a society to another is the greatest punishment imposed upon an offender by the Buddha. This is because Parajika is considered as the gravest offence a monk can commit. One who becomes offender under Parajika loses his entire priesthood. Some scholars believe that excommunicating an offender from his monastery and from the Sangha is similar to "banishment" in modern law. This punishment is known as Pabbajaniya Kamma (Act of banishment) in Chullawagga Pali. "But unlike the banishment from the state which involves various hard treatments, such as providing little or no food etc., the miscreant in Buddhist monasticism though excommunication is given a complete opportunity to lead a virtuous life in the lay society” (Baron, Byrne \& Branscombe, undated:448). Therefore, though the word "banishment" is similar in name, at conceptual level, there are big differences between these two concepts. When we compare this punitive method with modern educational process, the principal 


\section{A Comparative Study of Punishment in Buddhist and Western Educational Psychology}

or teacher cannot remove a student from a government school except in an exceptional case since it is accepted that every child has the right to receive his/her education until he/ she reaches a prescribed grade by the government. When such cases arise, parents as well as students tend to file a case against the teachers and the principal who imposed such a punishment at a human rights court.

In modern law, punishment of quarrelsome people depends on the damage the parties involved have experienced. Quarrelsome people can be found in any society. Teachers use physical punishment, depriving privileges and use blaming when these types of misbehavior occur in classrooms. Accepting the wrong-doing and making an arrangement to get rid of the error committed by the offender is highly appreciated in Buddhism. To this type of offence punishment in Buddhism is Tajjaneeya Kamma (Act of censure) according to which a Bhikkhu should obtain his purity by completing eighteen points under a special disciplinary action called “Abbhana”. Rev.Pandukka and Rev. Lohitaka are two Bhikkus who received this punishment. If someone does not accept the error and tries to get rid of it, he is punished under "Ukkephganiya Kamma” (Act of suspension) (Vin ).

\section{Commonalities And Differences Of Punishment In Buddhist And Western Education Psychology}

Since the Buddha's main objective was to moralize his disciples but not to hurt them punishment in Buddhism is humanistic. That is what modern psychologists mean when they argue that punishment should be strong enough to stop the undesirable behavior but not excessive. If this is not the case, there may be resentment against who administers the punishment (Lester \& Cherly, 2002:226). Moralizing is an approach that is discussed in western psychology too regarding punishment. In modern terms, punishment involves not only the behavior that should cease, but also elements of retribution or retaliation as well as to hurt the person who has committed the crime.

Since corporal punishments are not promoted in Buddhism, the offender does not experience physical sufferings in inhumane manner. The Buddha may have thought the net result of any kind of punishment was that it internalized oppression, humiliation, and degradation for both the giver and the receiver of the punishment ${ }^{4}$. Today, western countries have banned physical punishments of students by principals and teachers (Leach, 1994:259). Another researcher points out that Scandinavian countries and Austria have banned physical punishment in school education (David, 1998:259) too, but, in Canada, if the punishment is reasonable, there is no action taken against parents, teachers and principals for administering such punishment (Carole, Carol, Deborah \& Lorin 2007:248). The main problem arises regarding that the subjective nature of what is understood as "reasonable" and how to measure it.

\footnotetext{
${ }^{4}$ www.stophitting.com/indexphp.page=buddhistonpunish. Retrieved 13.12.2014
} 


\section{A Comparative Study of Punishment in Buddhist and Western Educational Psychology}

However, some modern psychologists believe punishment lowers the probability that a response will occur again (Coon \& Mitterer, 2009:237), whereas others have argued it is hard to erase from memory a type of behavior that has been punished: its memory can only be suppressed temporarily which may result into a later reoccurrence of the behavior in a reinforced form, usually in a safe setting. But some psychologists argue that punished behavior is not forgotten; it is suppressed. The temporary suppressed behavior may (negatively) reinforce the punishing behavior. It means the punishing behavior may reappear in safe setting (David, 1998:259). This is the reason the Buddha, in most cases, used positive rather than negative reinforcement such as punishment. When King Kosala wanted to use physical punishment against Angulimala to make him submit, the Buddha achieved the same outcome with the help of constructive learning strategy. Most western psychologists too show a tendency to use positive reinforcement: praise, approval and reward instead of physical punishment since aversive punishments encourage escaping learning (learning to make response in order to end an aversive stimulus), avoidance of learning (learning to respond in order to postpone or prevent discomfort and aggression) (David, 1998:259). Another important aspect of this issue is that children understand positive instructions more easily than negative ones (Ibid). The teacher who gives students constructive feedback, offering positive instructions instead of focusing on the negative aspects of the student's work can thus reduce the likelihood that the unwanted behavior will reoccur by directing the student towards an alternative. Similarly, in recent research it can be seen that if parents change to less punitive parenting, their children's level of aggression will decline (Thomas, Undated). If children are punished by parents and teachers in an aggressive way, they would think aggression is a way to cope with problems (David, 1998:259). Not only will these children become more likely to experience from adult depression, suicidal tendencies, alcohol and spousal abuse and physical brutality against children (Straus \& Kantor, 1994:543). As children observe the behavior of their parents and how the latter administer punishments, they may imitate their methods when dealing with friends, siblings and later in life with their own children. The parental model may exert a long-term and deep influence on their behavior (Ibid).

Some argue punishment should be matched in magnitude to the harm that has been caused ${ }^{5}$. Psychologists further say that the punisher should aim at the misbehavior not at the child (Lester \& Cherly 2002:226). This can be seen in the punitive system in Buddhist psychology too. Constantly, where a punitive action should be taken, the Buddha considered the nature of the error committed but not the person responsible for it. Therefore, the punitive methods in Buddhist psychology are more reasonable. However, at present, due to objective factors, there are some occasions where punishment is imposed by considering the person and his past records but not the error committed.

The Buddha imposed rules and punishment where necessary straight after the error. This theory is accepted even in BMod theory and it is called "immediacy". If the punisher gets more time to

${ }^{5}$ http://newlotus;buddhist/door.com/en/news/d/33371. Retrieved 1.11.2014

(C) The International Journal of Indian Psychology, ISSN 2348-5396 (e)| ISSN: 2349-3429 (p) | 39 


\section{A Comparative Study of Punishment in Buddhist and Western Educational Psychology}

punish the offender, this might separate the misbehavior and punishment by hours (Lester \& Cherly 2002:226). It is believed that for punishment to be most effective, the consequences must follow the behavior immediately (Miltenberger, 2008 :131), which, in modern psychology, this referred to as "contingency". For punishment to be most effective, the punishing stimulus should occur every time the behavior occurs (Ibid). If the punishment is applied at random times, the child is likely to perceive the parents as unpredictable - s/he is on a variable ration schedule of reinforcement.

Punishment can create fear. The person receiving the punishment may show improved behavior because of the fear not only of the punishable behavior but also of the person who administers it or of the situation in which it occurs (David, 1998:259). The final result of such type of punishment is the child may come to fear the punitive teacher and may end up desiring to avoid school. This theory is discussed descriptively in Pavlov's theory of "classical conditioning". Here, such children are helpless and depressed. To another psychologist, physical punishment entails increased risk of causing low- self esteem (Ibid). This was said by the Buddha, i.e. that all tremble at the prospect of becoming the target of violence; all fear of death; placing oneself in the position of others, do not cause harm to them; do not kill (Dham:129 PTS). This is called "Attupanayika Dhamma pariyaya" in Buddhist psychology.

According to Buddhism, punishment is given to the wrong-doer if he/she has done it intentionally. Even in the present judicial system, before a punishment is given, consideration is given to whether the error has been done by an average person intentionally or not. The analysis of the offender's mind in Buddhism is far more advanced than in the present judicial system.

Punishment was given to the right person for a specific behavior: this is called "target behavior" in modern psychology. Any punishment given out of that concept was rejected and corrected by the Buddha (TGha: 59 PTS). To Chulla Pantaka theraghata, first, the Buddha rejected physical punishment which is given without considering the cognitive level of the student; second, he corrected the wrong punishment imposed by his senior disciples; third, it was the Buddha's acceptance that no teacher can awake one's potentiality having punished him/her without understanding his/her mental differences and development; fourth, it is impossible to uplift one's potentiality by imposing physical punishment, as punishment should be given to the right person, for the right behavior and at the right time. It is an important lesson to modern teachers who punish students without proper understanding of the student's psycho-social background.

To modern psychologists, mostly, punishment tells the recipient what not to do but it does not communicate what the person should do. In Buddhism, when punishment is given, immediately after the punishment an Anusasana is delivered in order to explain what kind of action would be appropriate. This is another fine lesson that can be learned by present teachers from Buddhism so they can reduce the harmful damage caused by the punishment they administer. 


\section{A Comparative Study of Punishment in Buddhist and Western Educational Psychology}

\section{CONCLUSION}

Though western educational psychology imposes corporal and mental punishments as a negative reinforcement in classroom education, Buddhist psychology does not promote either physical or mental punishment in cognitive development process, since it does not provide any motivation to the learner to improve his/her academic level. In Buddhist psychology, mental punishments are also given in managerial problems where disciplinary actions should be taken, but not in academic environments. Given this, it is clear that Buddhist psychology rejects physical punishment in any setting: academic or managerial. At present, in modern educational process too there is a tendency to reject physical punishments due to its ineffective nature. They believe severe punishments are a poor way to eliminate unwanted behavior in most situations. In any case, both Buddhist and western psychologists believe that punishment conveys less information than reward. Presently, western psychology which has integrated some Buddhist psychology teachings, promotes positive reward-based education without relying on negative reinforcement. The Buddha is the first psychologists who emphasized that the recipient of punishment often responds with anxiety, fear and rage. Moreover, when we consider the purpose of the punishment in Buddhism, it is clear that it is at a deeper level than Western Psychology, since Buddhism expects to take the offender towards a higher spiritual attainment with offender's purity. Furthermore, some punishment-related strategies, policies and humanistic feelings followed by the Buddha provide many valuable insights to anyone who takes punitive actions to minimize its adverse effects. Finally, teachings on punishment in Buddhist psychology provide a sound guidance for policy makers, theorists as well as scholars to improve their findings about punishment towards a more humanistic approach in both theoretical and at practical level.

\section{Acknowledgements}

I would like to acknowledge the help of Prof. Chen Jian, my thesis supervisor, for his constructive feedback and his constant encouragement to complete this paper. This paper is related to my research as a doctorate candidate at Shandong University which would not have been possible without the Chinese Government Scholarship I have received.

\section{Abbreviations}

PTS- Pali Text Society

AN-Anguttara Nikaya

DN- Deegha Nikaya

MN-Majjima Nikaya

TGha-Thera Gatha

Dham -Dhammapada pali

Vin-Vinaya Pitaka

SPa- Samantha Pasadika

\section{Conflict of Interests}

The author declared no conflict of interests.

(C) The International Journal of Indian Psychology, ISSN 2348-5396 (e)| ISSN: 2349-3429 (p) | 41 


\section{A Comparative Study of Punishment in Buddhist and Western Educational Psychology}

\section{REFERENCE}

Bakke, B.L., Kavale, S., Burns, T., McCarten, J.R., Wilson, L., Maddox, \& Clearly, J. Multicomponent Intervention for Agitated Behavior in a Person with Alzheimer's disease. Journal of Applied Behavior Analysis, 27, 175-176

Baron, Robber, A., Byrne, Donne., Branscombe, Nyle, R.(Ed). (2008). Social psychology. New Delhi: Prentice Hall of India Private Limited

Carole, Wade., Carol Tavris., Deborah, Saucier \& Lorin Elias. (Ed). (2007). Psychology. Pearson Prentice Hall: Toronto

Coon, Dennis., \& Mitterer, John. O. (Ed). (2009). Psychology: Modules for active learning. Thomson Wadsworth

David. G, Mayer. (Ed). (1998). Psychology. Worth publishers: New York

Fink, Charles, K. (2012). Buddhism Punishment and Reconciliation: In Journal of Buddhist Ethics. 19, 371-395. 2012

John, W, Santrock. (Ed). (2006). Educational psychology. Dorling Kindersley (India) Pvt Ltd

Johnston, J. M., Pennypacker, H.S. (1981). Strategies and tactics of human behavioral research. Mahwah: NJ:Erlbaum

Lester. M, Sadrow., Cherly, A. Rickabaugh. (Ed). (2002). Psychology. McGraw Hill.

Miltenberger, Raymond,G.(2008). Behavior modification: Principals and procedures, Wadsworth

Samantapasadika, (1926), Hewavitharana Publication: Colombo

Straus, M.A. \& Kantor, G.k. (1994). Corporal punishment of adolescents by parents: A risk factor in the epidemiology of depression, suicide, alcohol, child abuse and wife beating. Adolescence, 29, 543-561

Thomas, E.M. Aggressive behavior outcomes for young children: Change in parenting environment predicts change in behavior. Ottawa: On; statistic Canada. Retrieved Nov 16, 2007, from http://www.statcan.ca/cgi-bin/downpub/listpub.cgi?catno=89-599MIE2004001

Woolfolk, Anita. (Ed). (2006). Educational psychology . Dorling Kindersley (India) Pvt, Ltd

How to cite this article: W Keerthirathne (2016), A Comparative Study of Punishment in Buddhist and Western Educational Psychology, International Journal of Indian Psychology, Volume 3, Issue 4, No. 57, ISSN 2348-5396 (e), ISSN: 2349-3429 (p), DIP: 18.01.023/20160304, ISBN: 978-1-365-23993-9 